\title{
THE ROLE OF INTERNATIONAL MARKETING IN THE PROCESS OF INCREASING COMPETITIVENESS OF AGRICULTURAL AND FOOD PRODUCTS*
}

\begin{abstract}
Countries, which have problems in the field of economic relations with aboard, usually misapply basic postulates and concepts of international marketing, as modern conceptions for achieving competitive advantage on international scale. Accordingly, this paper work researches the role of international marketing in the process of raising competitiveness of the agricultural and food products. Global marketing is facing a stronger and more complex challenge that needs faster and more subtle strategic responses. Namely, it must expect rapid changes, complex strategic situations, stricter and more unpredictable competition and changing mental maps of management, especially in regard to the affirmation of social awareness about the importance of respecting the environmental, social, political, cultural, and other components of the local market. Because the tastes, needs and consumer habits differ significantly, there is also justification for market segmentation of agri-food products.
\end{abstract}

Key words: competitiveness, international marketing, standards, agri-food products.

\footnotetext{
* This paper work is a result of the project No. 46006 - III "Sustainable agriculture and rural development in function realizing strategic goals of the Republic of Serbia in framework of Danube region", financed by the Ministry of Education and Science of the Republic of Serbia in 2011-2014.
} 


\section{Introduction}

There are many definitions that describe the concept of international marketing. Albaum and Peterson (1984) defined this concept as a way to focus on what it actually contains, arguing that international marketing is "a set of activities associated with marketing in foreign markets." This definition should include, among other things, exporting, importing and managing of foreign operations, and activities related to marketing, relevant to the products and services that cross national boundaries. This definition later was treated by Albaum, Duerr and Strandskov (2005), who defined it as "the marketing of goods, services and information across political boundaries". Ghauri and Cateora (2006) took a slightly different stance, defining it as "the performance of business activities that direct the flow of goods and services available to consumers or users from a large number of countries to achieve profit". Mühlbacher, Leihs and Dahringer (2006) also contributed to this issue, adopting a more comprehensive perspective, which states that "an international marketing is implementation of marketing orientation and marketing potential in international affairs", while Czinkota and Ronkainen (2007) claimed that "international marketing is a process of planning and conducting transactions across national borders for the exchange which meets the objectives of individuals and organizations." Finally, Doole and Lowe (2008) do not agree with the practice of the unified definition, arguing that the way in which international marketing is defined and interpreted depends on the degree of involvement of companies in the international market, and therefore they differentiate export marketing, international marketing and global marketing.

The key issue in all definitions of international marketing lies not in the way in which researchers describe the actual process, activities or transactions of international marketing, but in the fact that this process, these activities and transactions, take place across national and political boundaries.

On the other hand, the marketing of agricultural and food products basically means that agricultural producers and processors best achieve long-term goals and ensure vitality, if they are in their production and their overall business orientation facing customers and their needs. Functions involved in the marketing process of agricultural and food products are classified into three groups (Crawford, 1997):

- the exchange, which involves buying and selling;

- physical function, which includes storage, transport and processes (determined by the processing of agricultural products before presenting them to the market);

- improvement of the process, including standardization, financing, carrying out the risk and marketing intelligence collection, processing and interpretation of information for marketing decision-making. 
Reasons for turning company business to international market are numerous: production, market, technological, competitive and financial. It is interesting that for Serbian companies in the field of agriculture the primary motive for export is financial, while marketing and technological are almost non-existent (Rakita, 2001). Accordingly, international marketing can be described as a market direction and coordination of business activities in order to achieve successful internationalization of business entities and their adequate integration in the foreign environment.

From the standpoint of the company, the international marketing strategy enables to target marketing activities in a way that contributes to achieving the goals that they have in mind when making decisions about hiring international companies. At the level of the national economy, design of international marketing strategy means the achievement of a surplus in merchandise trade.

\section{The basic assumptions of competitive exports of agricultural sector}

The basic assumptions of providing the modern concept of competitiveness of domestic agricultural sector can be stated as follows:

- Increasing investment in technology and innovation, and productivity growth.

- Achieving higher production, changing its structure and ensuring stable export supply.

- Accomplishing the strict standards of quality control (adapting to the EU standards in the field of veterinary, sanitary and phyto-sanitary requirements, environment protection) and the overall harmonization of legislation with the WTO and the EU rules.

- Developing marketing strategies, accentuating non-price elements of competition and product brand.

- Organizing activities of domestic producers and exporters. One of the ways to increase the competitiveness of the Serbian economy and the agrarian sector is the development of the business environment through clusters or "sectoral clusters." Clusters are groups of related, export-oriented enterprises, with related institutions at the same location (customers, suppliers, competitors, universities, schools, advertising agencies, financial institutions, etc.).

Finally, no less important prerequisite of achieving competitive exports of agricultural products from Serbia is the entry into the WTO, which accounts for about $95 \%$ of the world trade. The WTO is very important for all countries in the world; a key element is the idea of reducing customs tariffs among member countries and subsidies to the domestic market as well as eliminating or minimizing export subsidies. The advantage to all members is that they trade on customs tariffs of the MFN (Most Favoured Nation), which basically means that whenever one member agrees to reduce tariffs on a bilateral basis, all other states benefit and gain the same conditions. It is certain that in the process of Serbia's accession, the WTO members will oppose to the survival of the cur- 
rent tariff rates and incentives that Serbia has, belonging to the so-called amber box. The WTO members will require most of the support from the "amber box" to be moved to the so-called "green box", which includes investment in rural development, environment, transport, packaging and other permitted actions. Actually, as part of its access range, the WTO is trying to carefully distinguish between subsidies that are harmful to international markets (amber box) and those that are not (green box). Entry to the WTO will be in accordance with national interest of Serbia, it is necessary, first of all, for the above to increase the overall productivity of domestic agriculture and its efficiency in order to enable Serbia to compete, in terms of price and quality, in the export markets and the domestic market, which will be opened by the very act of lowering tariffs. This will do most of the work required in the EU accession process, as most of the EU accession rules are based on those of the WTO. In this process, the most important thing is to determine a national strategy and to set priorities in order to protect the domestic market and the most vulnerable segments of the agricultural production in Serbia.

\section{International marketing of agri-food products}

Using comparative advantages and traditions, which Serbia has in the field of agricultural production, requires processes of transformation of local agriculture and all forms of business entities in the industry. At the same time, characteristics of agricultural products and their use as well as the characteristics of supply and demand, make the program of marketing activities of these products considerably specific. In designing international marketing of agricultural and food products it is useful to explore the work of Philip Kotler on marketing challenges faced today by businesses.

Namely, Kotler (2003) in his seminars gathered responses from numerous managers on how they see today's customers, which may be useful for the analysis of emerging trends in the international classification of agricultural products. Some of the responses were as follows (Kotler, 2003):

- customers are becoming more sophisticated and sensitive to price;

- customers have little time and require greater convenience;

- customers know that quality of products increases from one supplier to another;

- customers are less sensitive to the producer's brand and gaining acceptance of reseller brand and generic products.

According to the same source, the managers when asked how well are their marketing tools working answered as follows:

- their products are not much different than those of the competition;

- they forego a large number of expensive services and extras to get to the sale;

- their price forming promptly reacts to price forming of competitors;

- advertising becomes more expensive and less efficient;

- too much is spent on sales promotion. 


\section{Product}

The specificity of the product in the marketing mix of agricultural products derives from the very specifics of agricultural production, which is a consequence of its biological character. Namely, production program of agricultural producers is largely determined by the nature of soil, crop rotation, climate, the presence of vegetation period in crop and livestock production, and taking into account all of these factors, it needs to be done to adapt products to the market. In addition, given that agricultural products are largely homogeneous, there is little opportunity for product differentiation, especially those products that are inputs for the food industry. But, for those agricultural products, which are sold at the green market and/or through the supermarket, there are some possibilities for differentiation, primarily through two main characteristics of products, including: packaging and marking. A particular aspect of agricultural products is the quality and brand.

Packaging products for international markets. Packing problems in international marketing are related to: overcoming major geographic distance; overcoming numerous cultural differences; dealing with various environmental standards in the world. There is general agreement that there are two dominant and unavoidable functions of modern packaging: protective and promotional. It should be noted that the ecological thinking in the field of packaging ("green thinking") has become imperative in the EU, and despite the high cost it is often cheaper and more acceptable than the alternative - exclusion from the "market game". At the same time, the export of Serbian fruit to the European market does not limit quality, but quality is limited by firms that do not fulfil the strict procedures of harvesting, freezing, packing, loading and transportation. The quality of Serbian fruit (plums, raspberries) is unmatched in the rigorous European market, but their price is often decreased by poor packaging and lack of respect for some elements clearly specified in the contracts (e.g. delivery). Therefore, fruit with superior packaging and properly harvested achieved higher product prices, for example, plums from Poland, the Czech Republic, Hungary, Turkey, whose quality is behind that of the Serbian fruit.

Product marking is an essential element of the package, i.e. the status of agricultural products (these are the foods that affect health, are subject to deterioration, etc.). Product labelling (trademarks, declarations of origin and quality) significantly contributes to the differentiation of the product, which can be done from various autochthonous perspectives, namely healthy, organic food, etc. Product marking plays a crucial role because of the increasing presence of genetically modified foods (soy bean, sweet corn varieties BT 11, which is only allowed to be distributed in the EU, but not grown). In the EU-25, since April 2004 , there are valid obligations on marking of genetically modified foods in order to partially protect consumers, but clearly only those with higher incomes. 
The poor will still opt for the price, and other, even the medical criteria will fall into the water.

Constantly ensuring quality and compliance with standards of quality by observing the ISO 9000-2000 (adopted by the International Organization for Standardization in Geneva), technical regulations, and compliance with ISO 14000 standards (standards in the field of ecology), TQM (a process of continuous quality improvement of all processes, products and services, which includes all employees), and the like is one of the most important strategic elements of competitiveness in domestic and international markets. The overall quality is derived from the following premise of improving quality: quality in the eyes of the customer; quality must be reflected not only in the products of the company, but in all activities of the company; quality requires commitment of all employees; it requires partners with high quality; program quality is not able to save a bad product; quality can always be improved; quality does not have to cost more; quality is important, but not sufficient (Senić, 2000).

\section{Price}

The possibility to influence the prices of agricultural products is less than the price of industrial products. For a large number of agricultural products, generally speaking, there is a market of perfect competition. Both, on the supply and the demand side, there are more participants in the exchange of the homogeneous products. Regarding the impact on prices, both in theory and practice, two types of actors can be distinguished in the market of agricultural products: first, those who have the potential to significantly affect the market price of their products and, secondly, those who - by the nature of their activities (they work mainly in exchange of products such as wheat, industrial plants) - do not have that option. Since, most agricultural products have a stock exchange price, it is clear that international competition based on price, is more intensive. In this sense, Serbian producers and exporters (who cannot achieve price competitiveness for these products) turn to export of agricultural and food products that require more processing stages and for which there is a possibility of differentiation, either through regarding them as autochthonous products, high quality and/or environmental safety. An important element of competitiveness in the future of export of agricultural products from Serbia will be development and improvement of non-price aspects of competition: quality, innovation, design, packaging, reliability and speed of delivery, trademark, ability to satisfy the specific demands of consumers and the like.

\section{Distribution}

In Serbia, the producers of agricultural products have a limited choice of alternative sales channels in the domestic market. Namely, a large number of farmers directly sell their products to the nearest local market, consumers 
and/or retailers (middlemen), while a certain number of sales goes to processors. ${ }^{1}$ In Serbia, this area is a major marketing problem. Namely, the lack of a well-organized system of purchasing, efficient trade network and a traffic infrastructure prevents mobilization of all available market surplus in all areas of low demand and, at the same time, limits the exercise of the two fundamental objectives: consolidation of supply for export and balance, and decrease in the price in the domestic market.

Specifics of agricultural production and agricultural products (unevenly spatially distributed agricultural production, production seasonality, bulky products subject to deterioration) cause problems of distribution, namely channel sales, transportation and storage (stocks) of agricultural products in large developed countries. Therefore, the role of the productive world's stock exchanges and auctions is developed in trade of agricultural products.

\section{Promotion}

Promotion has less important role in the agricultural marketing program compared to industrial products. In general, large producers or associated manufacturers can have brand products. To stimulate primary demand for certain agricultural products, it is possible to go for a cooperative economic advertising of associated producers. In this context, it should be noted that in many countries there are joint programs of certain groups of producers, aiming to better place their products on the domestic market or for export. This is about a strategy that is normally implemented through generic advertising and promotion of certain products.

In addition, the generic advertising and promotion are not just an instrument of market competitiveness of individuals, but also a phenomenon that brings overall benefits in the form of spreading the knowledge to people about adequate nutrition.

Numerous companies have internationalized its business by franchising. Namely, the franchising system represents cooperation and mutual business relationship between independent economic entities that is regulated by franchising agreement, pursuant to which a franchiser-franchise holder gives right to franchisee to use the trademark or commercial formula marked by a sign (trade mark) according to clearly defined contract terms, with the obligation to provide permanent professional help with easier operation, and to charge a franchise.

Companies, such as McDonalds, KFC (Kentucky Fried Chicken) and Avis, entered the markets of numerous countries on the basis of their retail franchise concepts and, at the same time, made sure that their marketing is culturally relevant. For example, KFC in the United States is the world's largest chain

\footnotetext{
${ }^{1}$ A large number of demand for agricultural products takes place in the market places, which will have a significant role, until the trade radically reorganized and properly equipped (with adequate cold stores and warehouses) do not qualify for the high-quality and cost-competitive supply of the population.
} 
of fast-food chicken, which owns or gives franchise licence to 12,800 stores in 90 countries $-60 \%$ of them is located outside the United States (Kotler and Keller, 2006). Although the benefits of expansion of sales and the company's business beyond the borders of their country are beyond doubt, the company must, however, keep in mind numerous risks that accompany each international appearance. For example, a company might not understand foreign customer preferences and fail to offer sufficiently attractive product, the company might not understand the business culture of a certain country or the company might not know how to trade in a foreign market, it might not be able to evaluate some of the legislation, the risk of political revolution, the devaluation currencies and the like. The following are some examples of incorrect assessment of foreign markets and incorrect decisions in international marketing (Kotler, 2001):

- Kellogg Pop-Tarts cake collapsed in the UK, because the percentage of British households owning toasters is much lower than in the United States, and the product was too sweet for British tastes;

- General Foods Tang failed in France because it was advertised as a substitute for orange juice for breakfast; while the French drink only a little orange juice and almost never for breakfast;

- General Foods spent millions of dollars trying to introduce a mixture for making cakes for Japanese consumers. The Company has not recognized that only $3 \%$ of Japanese households own ovens. Then they offered the idea of baking cakes in pans for preparing rice, but they did not predict that Japanese use the container to keep the rice warm and ready to eat for the whole day.

\section{International marketing on the example of indigenous products of protected origin}

In Serbia, there are a number of specific and sensitive ecosystems, within which there is flora and fauna with a large number of biological types of international importance. Extremely rich gene pool of wild plants and animals as well as a large number of indigenous populations of cultivated plants and domestic animals are very important genetic resources for medicine, agriculture, forestry, biotechnology, and can be used for further economic development of our country. Serbia should exploit the existing potential and capacity to become a regional leader in conservation, management and utilization of genetic resources.

Traditional knowledge and cultural heritage are also an important component of agro-biodiversity of the Republic of Serbia. According to the Biodiversity Strategy of the Republic of Serbia for the period from 2011 to 2018, the role of agro-biodiversity is to increase production and food security, reduce pressure on the various, including vulnerable ecosystems, forests and endangered species (Biodiversity Strategy of the Republic of Serbia for the period from 2011 to 2018, 2011). It also contributes to the stability and sustainability of agroecosystems, diversification of organisms in nature, preservation of soil fertility, preservation of other ecosystem, etc. 
Genetic resources from Serbia can be used to obtain autochthonous products of protected origin in conditions of global change and place them in the European market. These products can be offered as products that are the result of the comparative advantages of Serbia in relation to the European market.

International marketing program for autochthonous products of protected origin is oriented at real and anticipated needs of European citizens as consumers, the economy and society, and effective product sales in the European market. Specifics of these products and their use as well as the characteristics of supply and demand affect that program marketing activities of these products are considerably specific. The primary importance of marketing in this area is reflected in the establishment of the communication flow between producers of local products of protected origin from Serbia and European consumers.

The product is a very important tool in the marketing program of autochthonous products of protected origin. In addition, it is important to make a distinction between products for direct consumption, which are not processed, except for cleaning, sorting and packaging (e.g. vegetables) and the second group, consisting of products for industrial processing as raw materials (e.g. crops, livestock and seq.). A large number of products falls into both categories, because they are used both for direct consumption of households and large consumers, and as a raw material for industrial processing. Briefly speaking, the specificity of autochthonous products of protected origin in the marketing mix of agricultural products is derived from specifics of agricultural production, which is a consequence of its biological character. The production program of agricultural producers is largely determined by the nature of soil, crop rotation, climate, the presence of vegetation period in crop and livestock production, and taking into account all of these factors, it needs to be done to adapt products to the market.

Regarding brand development of autochthonous products of protected origin from Serbia, it is important to point out that Serbia is still mainly exporter of raw agricultural products and has no other product in this sector which has a recognizable name in the world or in the European market. We are at the very beginning, and the creation of the brand, especially in the category of healthy food, can be developed only toward products with higher levels of processing, with respect to all internationally known and recognized certificates, quality standards, standards of food safety and the like. A very small number of agricultural and food products with geographical indications is standardized on national level (ham from Zlatibor, kačkvalj Pirot), and at the international level, as already pointed out, these products do not exist. In late nineties, Bulgarians and Slovaks have protected production of "plum brandy", and in the meantime Slovenes "took" Serbian distinctive product - chutney. We are now at the turning point. For example, we have the famous "sour cherry", with by far the highest content of ascorbic acid - vitamin C, which is bought mostly by Austrians and 
Germans. It succeeds in southern Serbia and no other kind of sour cherries in the world has this kind of composition. With respect to the content of bioactive substances, it can have a functional food label. Unfortunately, this kind of sour cherry is not protected and in exports Serbia achieves much lower price than its competitors (Chile and Poland). True, we have positive examples, but these are exceptions. Brandy "Bojovčanka" and "Yellow Wasps" already have protected name, and as such, they are recognized across national borders. Our "Ariljska" and "Valjevo" raspberry is quite famous in the world, but we have failed to protect the genotypes of the raspberry, and it lost its identity.

From the standpoint of price competitiveness of brand autochthonous products with protected origin, Serbia has different characteristics. Due to small holdings, it has higher costs of production for basic types of grain, which causes the price competitiveness in trade of these products. On the other hand, because of the relatively cheap labour, favourable climatic conditions and high quality, Serbia is competitive with vegetables, beef and lamb meat (meat-specific, namely with the high quality of young cattle, which are exported to the markets of Greece and Italy, to billing higher export prices than the global average). Generally, the ability to influence the prices of agricultural products is less than the price of industrial products.

The distribution of such activity includes all those activities that are necessary to produce a protected product of autochthonous origin from the manufacturer distributing to the European consumers and users of products. The producers of autochthonous products of protected origin are expected to:

- identify and define European geographical areas and identify potential customers;

- assess the level of unsaturated demand among customers within a defined market area;

- consider the competition in the market (knowledge of current and potential competitors, where are they located and what services they provide).

The basic role of promotion in this area is to inform potential European customers and develop their preference; incite to action, i.e. purchase the product. Promotion is the only instrument of communicative character, it is the most flexible instrument, which is directly associated with creating a name and reputation in the European market. Promotion at the international level has an additional form, which could be characterized as promotion of national identity and national export promotion. Companies in many countries seriously count on government assistance (information, financial and promotional) when they appear in the international market, and this support could be reasonably expected by the producers and exporters of agricultural products from Serbia. In this context, improving the image of the country of origin "Made in Serbia" (development of the image of environmentally clean land) is very important because it directly affects the image of certain products, which is reflected in the positive economic effects of the placement of indigenous products of protected origin. 


\section{Conclusion}

Most of agricultural products has stock exchange value, and international competition based on price is more intense. Bearing in mind the current level of production and the competitiveness of domestic producers, it can be concluded that we are assuming the fulfilment of quality control standards, in the global market regarding terms of export of agricultural products - we are competitive only if we differentiate the offer in terms of exports of high-quality products at higher processing stages, organic food products with the brand and/or mark of autochthonous origin. Agricultural products have little opportunity to implement a strategy of differentiation, but these products can best check the talent for marketing. Namely, the possibilities of differentiation are limited by the fact that the largest number of agricultural products and some food (raw meat) is homogeneous in its basic market, commercial and technological decisions. The exception is certainly production of food products, healthy, organic food (where there are significant opportunities for the development of the brand), and placement of agricultural products through supermarkets, where it is possible to differentiate the offer, mainly based on the packaging marking and labelling of products. Finally, the implementation of international marketing strategies, as a prerequisite for the competitiveness of agricultural producers and exporters in the world market, basically means the selection of the optimal combination strategy of market segmentation and product differentiation, which are often used simultaneously. 


\section{Literature:}

Albaum, G., Peterson, R.A. (1984). Empirical Research in International Marketing: 1976-1982, Journal of International Business Studies, 15(1), pp. 161-73.

Albaum, G., Duerr, E., Strandskov, J. (2005). International Marketing and Export Management (5 ed.). Essex: Pearson Education.

Crawford, I.M. (1997). Agricultural and Food Marketing Management (2), FAO, Rome, pp. 6-10.

Czinkota, M.R., Ronkainen, I.A. (2007). International Marketing (8 ed.), Mason, OH: Thompson Higher Education.

Doole, I., Lowe, R. (2008). International Marketing Strategy (5 ed.). London: Cengage Learning EMEA.

Ghauri, P., Cateora, P. (2006). International Marketing (2 ed.). Berkshire: McGraw-Hill Education.

Kotler, P. (2001). Marketing Management, Prentice-Hall, Inc., New Jersey.

Kotler, P. (2003). Kako kreirati, upravljati i dominirati tržištem, Adižes, Novi Sad.

Kotler, P., Keller, K.L. (2006). Marketing menadžment, Data status, Beograd.

Mühlbacher, H., Leihs, H., Dahringer, L. (2006). International Marketing: A Global Perspective (3 ed.). London: Thomson Learning.

Rakita, B. (2001). Medjunarodni marketing, Ekonomski fakultet. Beograd, pp. 36-37.

Senić, R. (2000). Marketing menadžment, Prizma, Kragujevac.

Biodiversity Strategy of the Republic of Serbia for the period from 2011 to 2018, the Ministry of Environment and Spatial Planning, Belgrade 2011. 
BRANKO MIHAILOVIĆ

DRAGO CVIJANOVIĆ

PREDRAG VUKOVIĆ

Instytut Ekonomiki Rolnictwa

Belgrad

\title{
ROLA MARKETINGU MIĘDZYNARODOWEGO W PROCESIE PODNOSZENIA KONKURENCYJNOŚCI ROLNICTWA I PRODUKTÓW SPOŻYWCZYCH
}

\begin{abstract}
Abstrakt
W krajach, w których stosunki gospodarcze z zagranica sa utrudnione, zazwyczaj dochodzi do niewłaściwego wykorzystania podstawowych postulatów i koncepcji marketingu międzynarodowego, rozumianego jako nowoczesnej koncepcji osiagania przewagi konkurencyjnej na arenie międzynarodowej. Niniejszy artykut bada role marketingu międzynarodowego $w$ procesie zwiększania konkurencyjności rolnictwa i produktów spożywczych. Marketing światowy musi sprostać poważniejszemu i bardziej złożonemu wyzwaniu, wymagajacemu szybszych i bardziej strategicznych rekcji, a mianowicie marketing światowy musi liczyć się z szybkimi zmianami, złożonymi sytuacjami strategicznymi, bardziej zacięta i mniej przewidywalna konkurencja oraz zmieniajacymi się mapami mentalnymi zarządzania, zwłaszcza $w$ odniesieniu do potwierdzania świadomości społecznej na temat znaczenia respektowania środowiskowych, społecznych, politycznych, kulturowych $i$ innych komponentów rynku lokalnego. Ponieważ gusta, potrzeby i nawyki konsumenckie znacznie się różnia, segmentacja rynku produktów rolno-spo$\dot{z} y w c z y c h$ także jest uzasadniona.
\end{abstract}

Słowa kluczowe: konkurencyjność, marketing międzynarodowy, standardy, produkty rolno-spożywcze.

Accepted for print: 03.12.2015. 